\title{
Effect Of Melissa Officinalis L. ON Oxidative Stress and BIOCHEMICAL PARAMETERS IN ALUMINUM TOXICITY IN RATS
}

\author{
By \\ Nehal Mohamed Belal \\ Nutrition and Food Science Dept., \\ Faculty of Home Economics, \\ Helwan University, Egypt
}

Research Gournal Specific Fducation

Faculty of Specific Education

SMansoura University

ISSUE NO. 35, JULY. 2014

مجلة بحوث التربية النوعية - جامعة المنصورة

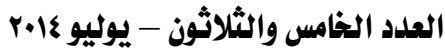




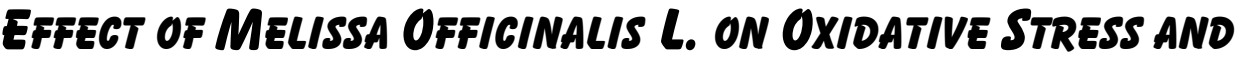 BIOCHEMICAL PARAMETERS IN ALUMINUM TOXICITY IN RATS
}

\author{
Nehal Mohamed Belal
}

\section{Abstract}

The main objective of this study was to investigate the effect of Lemon balm (Melissa officinalis, L.) on some nutritional parameters and liver enzymes, kidney functions, lipid profiles, acetyl cholinesterase activities and antioxidants activities for aluminum toxicity induced in rats. The experiment was carried out using thirty two male albino rats. The rats were divided randomly into two main groups, the first main group fed on the basal diet only as a negative control (normal group) while, the second main group were intraperitoneally injected with aluminum chloride $(\mathrm{AlCl} 3)$ to induce aluminum toxicity and divided into 3 subgroups (each 8 rats) as follow: Subgroup (1): was kept without any treatment as a positive control (+ve group) and fed on basal diet. Subgroups $(2 \& 3)$ : were fed on basal diet containing $4 \%$ and $8 \%$ lemon balm, respectively. At the end of the experiment period ( 8 weeks). Results indicated that, injected rats with $\mathrm{AlCl} 3$ increased significantly all the previous parameters, except FI, BWG \%, FER, high density lipoprotein, superoxide dismutase (SOD) activity, and total antioxidants that showed significant decreasing compared with (C-ve group). Also histopathological results of organs showed damage in them. In contrary, feeding rats on diets containing lemon balm especially at high level $(8 \%)$ revealed a marked improvement of these parameters and histopathological examinations of organs compared to +ve control group injected with $\mathrm{AlCl} 3$. The present study recommended that consuming lemon balm improved the symptoms of aluminum toxicity and prevent its complications.

Keywords: Melissa officinalis- Aluminum chloride- Acetyl cholinesterase - Antioxidants.

\section{INTRODUCTION}

$\mathrm{Al}$ is widely distributed in the environment and extensively used in daily life, which causes its easy exposure to human beings (Kumar and Gill, 2009). In fact, AL can be found in almost everywhere in food, beverages, cosmetics, toothpaste, cook ware, cans ,containers, and as adjuvant in 
different parenteral preparation and pharmaceutical agents. It has been shown that users of Al-containing antacids and buffered aspirin may have increased body $\mathrm{Al}$ (Krewski et al., 2007). Also, Al is added to drinking water for purification purposes (Turkez et al., 2010).

Workers in the industries related to $\mathrm{Al}$, are usually in a chronic exposure to $\mathrm{Al}$ more than that expected coming from normal daily diet. Al production workers who are occupationally exposed to $\mathrm{Al}$ have an oxidative stress situation that is evident in their blood (Ranjbar et al., 2008). As reviewed recently by (Mohammadirad and Abdollahi, 2011), most of toxicities of $\mathrm{Al}$ in human being are mediated through disturbing the balance between body oxidant and antioxidant. The most common condition related to $\mathrm{Al}$ exposure is Alzheimer's Disease (AD). $\mathrm{Al}$ is known to induce or worsen AD by its oxidant effects (Garcia et al., 2010). With the same mechanism of action, Al is known as a risk factor for Parkinson's disease (Sanchez-Iglesias et al., 2009). Since oxidant/antioxidant imbalance is involved in the pathogenesis of many diseases (Abdollahi et al., 2004) thus it would not be surprising to find strong links between $\mathrm{Al}$ exposure and many deliberating diseases other than $\mathrm{AD}$ and Parkinson.

Lemon balm (Melissa officinalis, L.) a member of Lamiaceae family is a perennial herb native to southern climates of Europe and North America (Sharafzadeh et al., 2011). Originally native to the east Mediterranean region and west Asia, Melissa officinalis (L.) (Lamiaceae) (lemon balm) is also encountered in certain tropical countries, such as Brazil, where it is popularly known as 'erva-cidreira' and 'melissa' (Souza et al., 2004). Aqueous and alcoholic extracts from the aerial part of Melissa officinalis are traditionally used in the treatment of fevers and colds, indigestion associated with nervous tension, hyperthyroidism, depression, mild insomnia, epilepsy, headaches, toothaches, and so on (Carnat et al., 1998; Herodez et al., 2003; Salah \&Jäger, 2005 and Dastmalchi et al., 2008). Furthermore, its antioxidant activity has been described by various authors (Mimica-Dukic et al., 2004; Souza et al., 2004 and Canadanovic-Brunet et al., 2008).

Lemon balm is used for several purposes such as an additive in food, a herb tea, an ingredient in cosmetics, an ornamental and a medicine(Sarı and Ceylan, 2002). Essential oil is currently used in medicine and pharmacology (anti-tumor, anti-bacterial, antimicrobial, antihistaminic, antispasmodic and antioxidant, by means of its antiviral effect curing of the herpes (Allahverdiyev et al., 2004) antiulcerogenic, moderate Alzheimer's disease, 
modulation of mood and cognitive performance, stimulating the immune system (against anti HIV-1) (Yamasaki, et al., 1998). In addition, lemon balm has traditionally been used due to its memory enhancing properties, but using of which is currently more widely used as sedative or calm, spasmolytic and antibacterial agent and sleep aid has been more popular recently(Coleta et al., 2011; Kennedy et al., 2004 and Sadraei et al., 2003).

Headspace solid-phase micro extraction (HS-SPME) coupled with gas chromatography-mass spectrometry (GC-MS) has been used for the chemical analysis of Melissa officinalis (leaves) cultivated in Institute Germplasm. The HS-SPME analysis led to the identification of 22 components constituting $99.1 \%$ of the total volatile constituents present in the leaves whereas its hydrodistillate led to the identification of 24 volatile constituents constituting $98.1 \%$ of the volatile material. The chemical composition of the SPME and hydrodistilled extract of M. officinalis leaves comprised mainly of oxygenated monoterpenes $(78.5 \%$ and $57.8 \%$ respectively) and sesquiterpene hydrocarbons (14.9 and $29.7 \%$, respectively). The major components identified in the HS-SPME extract were citronellal $(31.1 \%)$, citronellol (18.3\%), b-caryophyllene $(12.0 \%),(\mathrm{E})$ citral (11.9\%), (Z)-citral (9.6\%), geraniol (3.6\%), (Z)-b-ocimene $(3.1 \%)$ and 1-octen-3-ol (2.0\%) whereas hydrodistilled essential oil was rich in (Z)citral (19.6\%), b-caryophyllene (13.2\%), (E)-citral (11.2\%), citronellal $(10.2 \%)$, germacrene-D (8.3\%), d-3-carene (5.0\%), 6-methyl-5-hepten-2one $(3.7 \%)$ and citronellyl acetate (3.7\%) (Rehman et al., 2013).

\section{Material and Methods}

\section{- Materials}

Lemon balm (Melissa officinalis, L.) leaves were purchased as dried material from spice dealer from local market in Cairo. Anhydrous aluminum chloride $(\mathrm{AlCl} 3)$ was obtained from Sigma Chemical Co. Casein (> 85\% protein) was obtained from Misr Scientific Company, Giza, Egypt. Cellulose and DL- methionine were purchased from Morgan Company, Cairo, Egypt. Minerals and vitamins constituent, sucrose, glucose and absolute ethanol were obtained from El-Gomhoriya Pharm. and Chem. Ind. Co. Cairo, Egypt. Corn oil was obtained from the local market. Corn starch was obtained from Starch and Glucose Company, Helwan, Egypt. 


\section{- Animals}

Thirty two male albino rats, Sprague Dawley strain, weighing (135 \pm $10 \mathrm{~g}$ ) were purchased from the animal house of Agriculture Research Center, Giza, Egypt. The animals were housed in plastic cages, maintained on a natural light-dark cycle at room temperature of $26 \pm 2^{\circ} \mathrm{C}$ and fed standard diet according to Reeves et al., (1993) and water ad libitum. Rats were kept for one week as acclimatization period before the start of the experiment. All rats were handled in accordance with the standard guide for the care and use of laboratory animals.

\section{- Methods:}

\section{Preparation of plant formulations:}

Lemon balm leaves were milled in a mixer to give a powder and kept in dusky stoppered glass bottles in a dry location till using.

\section{Experimental design:}

The experiment was performed in Animal House in the Food Technology Research Institute, Agriculture Research Center, Giza. After the acclimatization period, rats were divided randomly into two main groups, the first main group ( $\mathrm{n}=8$ rats) fed on the basal diet only as a negative control (normal group) and intraperitoneally injected with saline solution. While, the second main group $(n=24$ rats) were intraperitoneally injected with $\mathrm{AlCl} 3$ at dose of $(20 \mathrm{mg} / \mathrm{kg}$ bw.) 4 times weekly to induce aluminum toxicity according to Berlyne et al., (1972).

The second main group (injected with $\mathrm{AlCl} 3$ ) was divided into 3 subgroups (each 8 rats) as follows: Subgroup (1): was kept without any treatment as a positive control ( $\mathrm{C}+\mathrm{ve}$ group) and fed on basal diet. Subgroups ( $2 \& 3)$ : were fed on basal diet containing $4 \%$ and $8 \%$ lemon balm respectively. Body weight (BW) was recorded weekly during the experimental period and feed intake was measured daily during the experimental periods.

\section{Blood sampling:}

At the end of the experiment period ( 8 weeks), rats were sacrificed after overnight fasting under ether anesthesia. Blood samples were taken from hepatic portal vein and were left to clot by standing at room temperature for 15 minutes, and then centrifuged at $3000 \mathrm{rpm}$ for 20 
minutes. Serum was carefully separated and transferred into clean quite fit plastic tubes and kept frozen at $-20^{\circ} \mathrm{C}$ until the time of analysis.

\section{Biological evaluation:}

At the end of the experiment, biological evaluation of the tested diets was carried out by determining total feed intake (FI), body weight gain\% (BWG\%) and Food efficiency ratio (FER) according to Chapman et al., (1959).

\section{Biochemical analysis:}

\section{Determination of liver enzymes:}

Serum alanine and aspartate aminotransferases (ALT \& AST) were estimated according to Reitman and Frankel, (1957) while alkaline phosphatase (ALP) was assayed by (Kind and King, 1954).

\section{Determination of kidney functions:}

Serum creatinine, uric acid and urea were determined according to the methods described by Bohmer, (1971); Fossati et al., (1980) and Patton and Crouch, (1977), respectively.

\section{Determination of serum lipids:}

Enzymatic colorimetric determination of triglycerides was carried out according to Fossati and Prencipe, (1982). Total cholesterol was determined by colorimetric method according to Allian et al., (1974). Determination of HDL (high density lipoprotein) was carried out according to the method of Fnedewaid, (1972). The determination of VLDL (very low density lipoproteins) and LDL (low density lipoproteins) were carried out according to the method of Lee and Nieman, (1996) by calculation as follows:

$*$ VLDL $(\mathrm{mg} / \mathrm{dl})=$ Triglycerides $/ 5$

* LDL $(\mathrm{mg} / \mathrm{dl})=$ Total cholesterol $-\mathrm{HDL}-\mathrm{VLDL}$

\section{Determination of serum acetycholinesterase and antioxidant parameters}

Acetycholinesterase (AchE) activity was determined according to Knedel and Boottger, (1967). Superoxide dismutase (SOD) activity, total antioxidants capacity (TAC), and malondialdehyde (MDA) were determined according to Nishikimi et al.,(1972); Cao et al., (1993) and Ohkawa et al.,(1979), respectively. 


\section{Histopathological examination:}

Liver, kidney and brain sections were taken from different rats in each group immediately after sacrification. The tissues were washed with the normal saline solution to remove blood, fixed in $10 \%$ neutral formalin as fixative and sent to Cancer Institute for histopathological examination according to Bancroft et al., (1996).

\section{Statistical analysis:}

The obtained data were statistically analyzed using computerized SPSS (Statistic Program Sigmastat, Statistical Soft-Ware, SAS Institute, Cary, NC). Effects of different treatments were analyzed by one way ANOVA (Analysis of variance) test using Duncan's multiple range test and $\mathrm{p}<0.05$ was used to indicate significance between different groups (Snedecor and Cochran, 1967).

\section{Results}

Effect of lemon balm on body weight gain, feed intake and food efficiency ratio \% in rats received $\mathrm{AlCl} 3$ was illustrated in table (1). It could be noticed that group received $\mathrm{AlCl} 3$ (+ve) control recorded a significant decrease in body weight gain BWG, feed intake (FI), and food efficiency ratio \% (FER\%) compared with healthy control group. Whereas, BWG, FI and FER $\%$ of all treated groups increased significantly compared with (+ve) control untreated group, however it could not reach the normal value recorded by healthy control group.

Table (1): Effect of lemon balm on body weight gain, feed intake and Food efficiency ratio $\%$ in rats received $\mathrm{AlCl} 3$.

\begin{tabular}{|c|c|c|c|c|}
\hline & $\begin{array}{l}\text { Parameters } \\
\text { Groups } \\
\end{array}$ & $\begin{array}{l}\text { Body weight gain } \\
(\mathrm{g})\end{array}$ & $\begin{array}{c}\text { Feed intake } \\
\text { g/day }\end{array}$ & $\begin{array}{c}\text { Food } \\
\text { efficiency } \\
\text { ratio (FER) \% } \\
\end{array}$ \\
\hline \multirow{4}{*}{$\frac{m}{\circlearrowright}$} & Normal control group & $138.0 \pm 7.0 \mathrm{a}$ & $17.9 \pm 0.58 \mathrm{a}$ & $0.179 \pm 0.04 \mathrm{a}$ \\
\hline & (+) control group & $99.0 \pm 5.3 \mathrm{c}$ & $16.3 \pm 0.58 \mathrm{c}$ & $0.163 \pm 0.01 \mathrm{c}$ \\
\hline & $40 \mathrm{~g}$ lemon balm $/ \mathrm{kg}$ diet & $116.6 \pm 6.9 \mathrm{~b}$ & $17.3 \pm 0.37 \mathrm{~b}$ & $0.172 \pm 0.00 \mathrm{~b}$ \\
\hline & $80 \mathrm{~g}$ lemon balm $/ \mathrm{kg}$ diet & $125.0 \pm 7.6 \mathrm{~b}$ & $17.4 \pm 0.45 \mathrm{~b}$ & $0.173 \pm 0.01 \mathrm{~b}$ \\
\hline
\end{tabular}

Values are expressed as mean \pm SD. Significance at $p<0.05$.

Values which don't share the same letter in each column are significantly different. 
Effect of lemon balm on liver functions in rats received $\mathrm{AlCl} 3$ was illustrated in Table (2). It could be observed that, the mean values of serum AST, ALT and ALP enzymes in the positive control group increased significantly as compared to the healthy control group. Addition of lemon balm to the diet (all tested levels) showed a significant decrease in mean value of serum AST, ALT and ALP enzymes activity than the positive control group especially, the high level $8 \%$ for AST and ALP.

Table (2): Effect of lemon balm on liver functions in rats received $\mathrm{AlCl} 3$.

\begin{tabular}{|c|c|c|c|c|}
\hline \multicolumn{2}{|r|}{ Groups } & $\begin{array}{c}\text { AST } \\
\text { Activity (Iu/l) } \\
\end{array}$ & $\begin{array}{c}\text { ALT } \\
\text { Activity (Iu/l) } \\
\end{array}$ & $\begin{array}{c}\text { ALP } \\
\text { Activity (Iu/l) } \\
\end{array}$ \\
\hline \multirow{4}{*}{$\frac{m}{\mathbb{U}}$} & Normal control g & $50.33 \pm 1.53 c$ & $38.67 \pm 1.15 \mathrm{c}$ & $198.21 \pm 8.00 \mathrm{c}$ \\
\hline & (+) control group & $82.33 \pm 3.05 \mathrm{a}$ & $60.66 \pm 3.21 \mathrm{a}$ & $272.13 \pm 13.10 \mathrm{a}$ \\
\hline & 40g lemon balm $/ \mathrm{kg}$ diet & $61.67 \pm 3.78 b$ & $44.67 \pm 3.05 b$ & $220.14 \pm 11.06 b$ \\
\hline & $80 \mathrm{~g}$ lemon balm $/ \mathrm{kg}$ diet & $51.01 \pm 1.00 \mathrm{c}$ & $45.66 \pm 2.08 \mathrm{~b}$ & $201.21 \pm 9.17 \mathrm{c}$ \\
\hline
\end{tabular}

Values are expressed as mean \pm SD. Significance at $\mathrm{p}<0.05$.

Values which don't share the same letter in each column are significantly different

Effect of lemon balm on kidney functions in rats received $\mathrm{AlCl} 3$ was illustrated in Table (3). Data revealed that, injected rats with $\mathrm{AlCl} 3$ led to significant increase in serum creatinine, urea and uric acid as compared to (non-injected ) normal group of rats. Treating $\mathrm{AlCl} 3$ groups with any level from lemon balm resulted in significant decrease in all mean values of kidney functions.

Table (3): Effect of lemon balm on kidney functions in rats received $\mathrm{AlCl} 3$.

\begin{tabular}{||c|c|c|c|c||}
\hline \hline \multicolumn{2}{|c|}{$\begin{array}{c}\text { Parameters } \\
\text { Groups }\end{array}$} & $\begin{array}{c}\text { Creatinine } \\
\mathrm{mg} / \mathrm{dl}\end{array}$ & $\begin{array}{c}\text { Urea } \\
\mathrm{mg} / \mathrm{dl}\end{array}$ & $\begin{array}{c}\text { Uric acid } \\
\mathrm{mg} / \mathrm{dl}\end{array}$ \\
\hline \hline \multirow{3}{*}{$\underset{\mathrm{U}}{*}$} & Normal control group & $1.03 \pm 0.06 \mathrm{~b}$ & $49.01 \pm 1.02 \mathrm{c}$ & $3.01 \pm 0.12 \mathrm{~b}$ \\
\cline { 2 - 5 } & $(+)$ control group & $1.47 \pm 0.2 \mathrm{a}$ & $65.33 \pm 2.52 \mathrm{a}$ & $4.78 \pm 0.18 \mathrm{a}$ \\
\cline { 2 - 5 } & $40 \mathrm{~g}$ lemon balm $/ \mathrm{kg}$ diet & $1.13 \pm 0.06 \mathrm{~b}$ & $54.33 \pm 3.05 \mathrm{~b}$ & $3.26 \pm 0.26 \mathrm{~b}$ \\
\cline { 2 - 5 } & $80 \mathrm{~g}$ lemon balm /kg diet & $1.07 \pm 0.06 \mathrm{~b}$ & $50.67 \pm 3.06 \mathrm{bc}$ & $3.20 \pm 0.18 \mathrm{~b}$ \\
\hline
\end{tabular}

Values are expressed as mean \pm SD. Significance at $\mathrm{p}<0.05$.

Values which don't share the same letter in each column are significantly different.

Effect of lemon balm on lipid profile in rats received $\mathrm{AlCl} 3$ are presented in Table (4). Total serum cholesterol, triglycerides, LDL-c and VLDL-c increased significantly in the positive control group (group received $\mathrm{AlCl} 3$ ) as compared to healthy group. All groups of rats which treated with the two levels of lemon balm had a significant decrease in the mean values of serum total cholesterol, triglycerides, LDL-c and VLDL-c 
comparing to the $\mathrm{AlCl} 3$ positive control group especially at high level (8\%) that revealed a marked improvement of these parameters. The mean value of HDL-c decreased significantly in (+ve) control group compared to (-ve) control group. Whereas, the treated groups of rats with lemon balm showed significant higher mean values of HDL-c than that of the (+ve) control group especially at high level (8\%). The best results for all lipoproteins were noticed in the groups of rats fed on diet containing high level (8\%) lemon balm as compared to $4 \%$ low level treated group.

Table (4): Effect of lemon balm on lipid profile in rats received AlCl3 .

\begin{tabular}{|c|c|c|c|c|c|c|}
\hline & $\begin{array}{l}\text { Parameters } \\
\text { Groups }\end{array}$ & $\begin{array}{c}\mathrm{TC} \\
\mathrm{mg} / \mathrm{dl}\end{array}$ & $\begin{array}{c}\mathrm{TG} \\
\mathrm{mg} / \mathrm{dl}\end{array}$ & $\begin{array}{c}\mathrm{LDL}-\mathrm{c} \\
\mathrm{mg} / \mathrm{dl}\end{array}$ & $\begin{array}{c}\text { VLDL-c } \\
\mathrm{mg} / \mathrm{dl}\end{array}$ & $\begin{array}{c}\mathrm{HDL}-\mathrm{c} \\
\mathrm{mg} / \mathrm{dl}\end{array}$ \\
\hline \multirow{4}{*}{$\frac{m}{\frac{\varrho}{4}}$} & $\begin{array}{c}\text { Normal } \\
\text { control group }\end{array}$ & $103.00 \pm 12.10 \mathrm{~d}$ & $148.00 \pm 11.00 \mathrm{~d}$ & $48.67 \pm 3.51 b$ & $29.60 \pm 1.20 \mathrm{~d}$ & $44.12 \pm 1.73 \mathrm{a}$ \\
\hline & $\begin{array}{l}(+) \text { control } \\
\text { group }\end{array}$ & $140.67 \pm 13.79 a$ & $245.01 \pm 13.61 \mathrm{a}$ & $71.33 \pm 2.08 \mathrm{a}$ & $49.01 \pm 1.72 \mathrm{a}$ & $28.67 \pm 1.21 \mathrm{~d}$ \\
\hline & $\begin{array}{c}40 \mathrm{~g} \text { lemon } \\
\mathrm{balm} / \mathrm{kg} \text { diet }\end{array}$ & $115.67 \pm 11.53 b$ & $213.67 \pm 14.04 b$ & $34.00 \pm 2.00 \mathrm{c}$ & $42.73 \pm 1.81 b$ & $32.02 \pm 1.11 \mathrm{c}$ \\
\hline & $\begin{array}{c}80 \mathrm{~g} \text { lemon } \\
\mathrm{balm} / \mathrm{kg} \text { diet }\end{array}$ & $109.33 \pm 12.08 \mathrm{c}$ & $161.33 \pm 11.53 \mathrm{c}$ & $35.67 \pm 2.31 \mathrm{c}$ & $32.27 \pm 1.31 \mathrm{c}$ & $39.69 \pm 1.53 b$ \\
\hline
\end{tabular}

Values are expressed as mean \pm SD. Significance at $\mathrm{p}<0.05$.

Values which don't share the same letter in each column are significantly different.

Effect of lemon balm on antioxidant parameters and acetyl cholinesterase in rats received $\mathrm{AlCl} 3$ were illustrated in table (5). It could be observed that the mean value of serum malondialdehyde and acetyl cholinesterase in +ve control untreated group was significantly higher than in healthy control group. All levels of lemon balm were able to reduce serum MDA and acetyl cholinesterase significantly compared with untreated group especially at high level $8 \%$.

In general, the best result of MDA and acetyl cholinesterase activity was noticed in group treated with the high mixture ( $80 \mathrm{~g}$ lemon balm/ $/ \mathrm{kg}$ diet) as its mean value was the nearest from that recorded by the healthy control group. Followed, group of (40g lemon balm $/ \mathrm{kg}$ diet). Regarding the mean values of serum total antioxidant and superoxide dismutase in +ve control group received $\mathrm{AlCl} 3$ were significantly lower than in healthy control group. In general, the best result was noticed also in group treated with the high level 8\% lemon balm. 
Results of the histopathological examination of liver, kidneys and brain of rats from different experimental groups were illustrated in histopathological images. The obtained biochemical results are confirmed by the histopathological examination. The best results of liver, kidneys and brain were noticed also in groups treated with the higher level $(80 \mathrm{~g} / \mathrm{kg}$ diet) of lemon balm followed (40g lemon balm $/ \mathrm{kg}$ diet) group.

Table (5): Effect of lemon balm on antioxidant parameters and Acetyl cholinesterase in rats received $\mathrm{AlCl} 3$

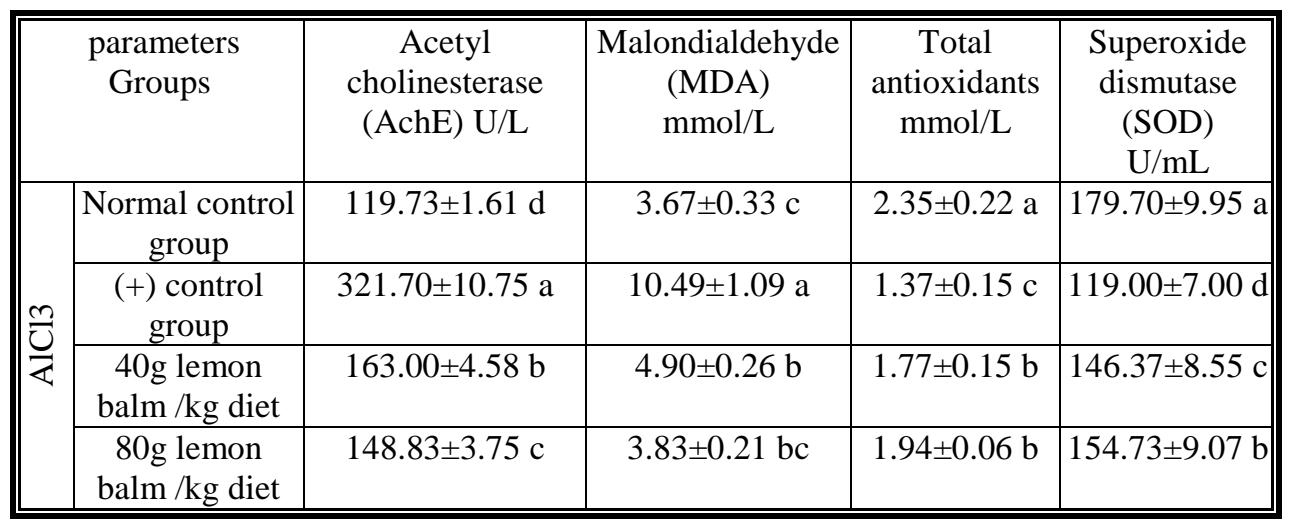

Values are expressed as mean \pm SD. Significance at $\mathrm{p}<0.05$.

Values which don't share the same letter in each column are significantly different.

Results of the histopathological examination of liver, kidneys and brain of rats from different experimental groups were illustrated in histopathological images. The obtained biochemical results are confirmed by the histopathological examination. The best results of liver, kidneys and brain were noticed also in group treated with the higher level $(80 \mathrm{~g} / \mathrm{kg}$ diet $)$ of lemon balm followed $(40 \mathrm{~g} / \mathrm{kg}$ diet) group. 


\section{Histopathological of the brain}

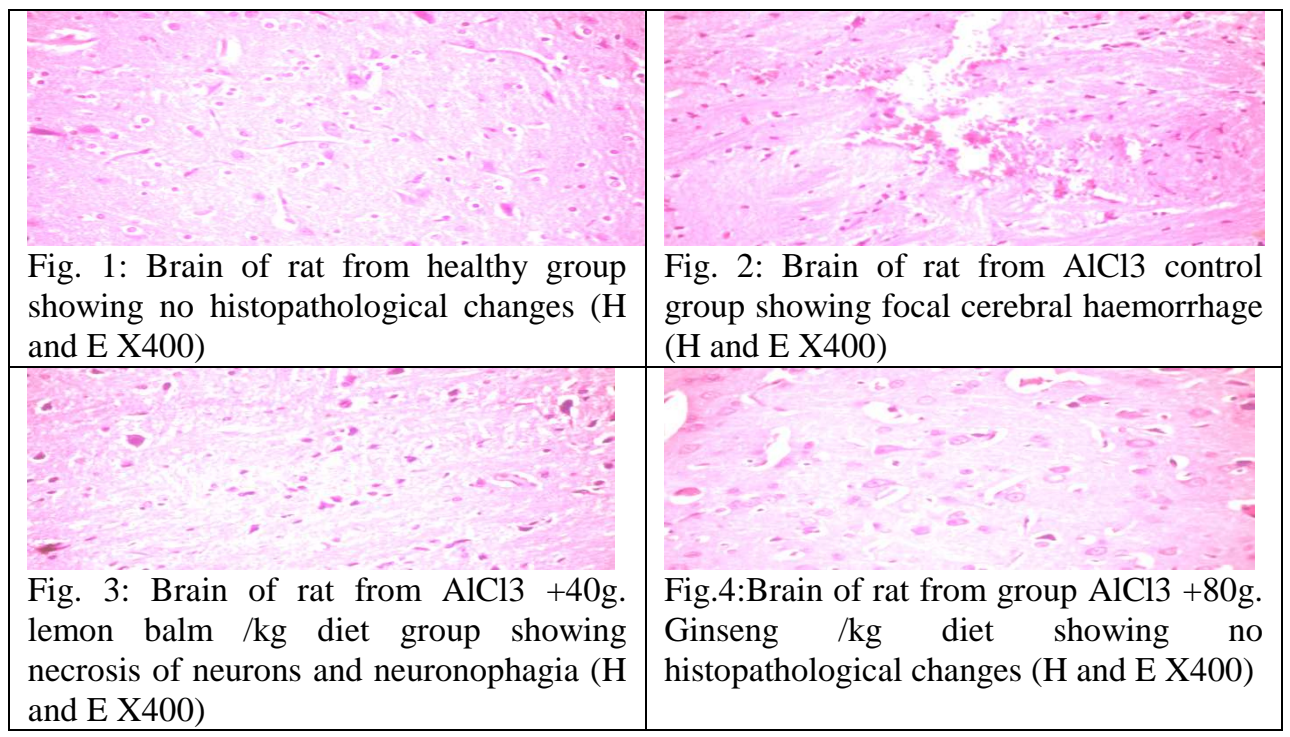

\section{DISCUSSION}

Treatment with $\mathrm{AlCl} 3$ recorded a significant decrease in body weight gain, feed intake, and food efficiency ratio \% of +ve group compared with healthy control group. In this respect Domingo, (1987) found a significant decrease in body weight gain associated with a decrease in food consumption at $260 \mathrm{mg}$ of aluminium per $\mathrm{kg}$ of body weight per day.

$\mathrm{Al}$ accumulates in all tissues of the mammals, including kidney, liver, heart, blood, bone and brain (Al-Kahtani, 2010). Accumulation of $\mathrm{Al}$ in liver produces hepatic injury at higher concentrations (Shati and Alamri, 2010). Al ions alter properties and structure of cellular membranes, inhibit many enzymes like alkaline phosphatase, and adenyl cyclase (Qitu et al., 2002 ). Kidney plays a major role in preventing accumulation of Al by excreting it out through urine (Stoehr et al., 2006). Accumulation of Al induces free radicals and oxidative stress. Al is one of the most studied neurotoxicant affecting nervous system, including various regions of brain (Nehru and Bhalla, 2006). Some experts believe that Al plays a role in the formation of Alzheimer like neurofibrillary tangles (Sharma et al., 2009). Antagonistic interactions between $\mathrm{Al}$ ions and other elements such as: calcium, magnesium, iron, silicon, phosphorus, copper, and zinc were observed in biological systems (Ward et al., 2001). 
It could be observed that, the mean values of serum AST, ALT and ALP enzymes in the positive control group increased significantly as compared to the healthy control group. In this respect, Molecular changes such as DNA damages and gene suppression or expression may happen to hepatic cells when the model animal exposed to toxic materials (Burham, 2006). Aluminum has been reported to affect the activities of translation machinery components in mouse liver in vivo and in vitro as $\mathrm{Al}$ can bind to phosphorylated bases on DNA, induce considerable changes in chromatin structure and disrupt protein synthesis, and catabolism (El-Demerdash, 2004 and Vieželienè et al., 2006).

Addition of lemon balm to the diet (all tested levels) showed a significant decrease in mean value of serum AST, ALT and ALP enzymes activity than the positive control group especially, at the high level $8 \%$ for AST and ALP. In support of the present findings, Administration of Melissa officinalis L. extract reduced total cholesterol, total lipid, ALT, AST and ALP levels in serum and LPO levels in liver tissue, moreover increased glutathione levels in the tissue (Bolkent et al., 2005). In this respect, Molecular changes such as DNA damages and gene suppression or expression may happen to hepatic cells when the model animal exposed to toxic materials (Burham, 2006). Aluminum has been reported to affect the activities of translation machinery components in mouse liver in vivo and in vitro as $\mathrm{Al}$ can bind to phosphorylated bases on DNA, induce considerable changes in chromatin structure and disrupt protein synthesis, and catabolism (El-Demerdash, 2004 and Vieželienè et al., 2006).

Injected rats with $\mathrm{AlCl} 3$ led to significant increase in serum creatinine, urea and uric acid as compared to (non-injected ) normal group of rats. Treating $\mathrm{AlCl} 3$ groups with any level from lemon balm resulted in significant decrease in all mean values of kidney functions. These results were agreement with Birdane et al., (2007) who showed that, antioxidative properties and radical scavenging activity may be the possible mechanisms. Phytochemical studies carried out with M. officinalis have demonstrated the numerous constituents, polyphenolic compounds (rosmarinic acid, caffeic acid and protocatechuic acid), essencial oils (citral), monotherpenoid aldehides, sesquiterpenes, flavonoids (luteolin) and tannins (Carnat et al., 1998 and Guginski et al., 2009). Pharmacological investigation concerning its essential oil has revealed that, besides this being an efficient antibacterial and antifungal agent (Mimica-Dukic et al., 2004), it is also endowed with 
intrinsic anxiolytic properties (Pereira et al., 2005). The antioxidant and antitumoral properties are implied from a literature that is mainly addressed to core components, other than extracts or infusions per se (Souza et al., 2004; Pereira et al., 2009 and Carvalho et al., 2011). Natália Cassettari de Carvalho1, Maria Júlia Frydberg Corrêa-Angeloni1, Daniela Dimer Leffa1

Use of Lemon balm infusion in $\mathrm{Al}$ groups caused a significant increase in serum antioxidants and a significant reduction in hepatic and lipid markers. This results in agreement with Randell et al., (2005) who noticed that, exposure to Al can affect the triglyceride metabolism and triglyceride concentrations in the body. In this regarding, Aluminum has been found to cause oxidative stress in the plasma and the tissues of male rabbits. The mechanism of $\mathrm{Al}$ induced toxicity has been attributed to its ability to potentiate the activity of iron $\mathrm{Fe} 2+$ and $\mathrm{Fe} 3+$ ions in such a way as to cause oxidative damage (Newairy et al., 2009 and Burham, 2006). In the body, non-enzymatic anti-oxidation including GST and enzymatic antioxidation including GPx, CAT, and SOD occur to protect cell membranes and intracellular materials from reactive oxygen species, including free radicals. SOD is a very important enzyme in the body produced in the early stage of free radical generation, converting superoxide into $\mathrm{O} 2$ and $\mathrm{H} 2 \mathrm{O} 2$. GPx and CAT eliminate the $\mathrm{H} 2 \mathrm{O} 2$ produced during the enzymatic reaction by SOD to protect the body from peroxidative damage.

Acetylcholine (ACh) is an important neurotransmitter that plays a critical role in memory and learning processes. In central cholinergic systems, ACh is synthesized from choline and acetyl-CoA by choline acetyltransferase (ChAT) (Ohno et al., 2001). After being delivered in the synapses, ACh is hydrolyzed, resulting in choline and an acetyl group in a reaction catalyzed by the enzyme cholinesterase (ChE) (Ballard et al., 2005). $\mathrm{ChE}$ is distinguished primarily by its substrate specificity. Acetylcholineserase (AChE) hydrolyzes ACh more efficiently than other choline esters, while butyrylcholinesterase (BuChE) hydrolyzes mainly butyrylcholine (BCh) among other types of ACh. Therefore, the effectiveness of ginseng extracts against memory loss may result from the cholinergic activity of these extract via reduction of the degradation rate of $\mathrm{ACh}$ by inhibition of the $\mathrm{ChE}$ activity (for both types of $\mathrm{ChE}$ ) (Mi et al., 2011).

Many in vitro and ex vivo studies have shown antioxidant activity of Melissa officinalis extracts but in vivo studies especially in 
human are rare. In vivo studies just showed that Melissa officinalis L. extract could decrease LPO in rodents (Birdane et al., 2007) and in liver tissue of hyperlipidemic rats (Bolkent et al., 2005) and in radiology staff (Zeraatpishe et al., 2011). Melissa officinalis L. extract has been useful as rich source of antioxidants (Dastmalchi et al., 2008). The main phenolic compounds which were identified in tea infusion from Lemon balm were rosmarinic acid, luteolin 7-O-glucoside, quercetin 3-rutinoside, gallic acid, quercetin 3-O galactoside and ferulic acid. Lemon balm contains a rich source of natural antioxidants and effective in many oxidant-related disorders (Hasani-Ranjbar et al., 2009). A recent study indicated that Lemon balm is beneficial in protection against oxidative stress and DNA damage in subjects exposed to long-term low-dose ionizing radiation (Zeraatpishe et al., 2011). Hence, it seems that Lemon balm, due to its antioxidant components and scavenging properties could increase the activity of antioxidant defense and decrease oxidative stress and triglyceride, cholesterol and AST in Al toxicity. CONCLUSION: It could be concluded that, addition lemon balm to the diet are effective in protect the body from the oxidative stress induced by aluminum chloride.

\section{References}

- Abdollahi, M.; Ranjbar, A.; Shadnia, S.; Nikfar, S. and Rezaie, A. (2004): Pesticides and oxidative stress: A review. Med. Sci. Monit.; 10: RA141RA147.

- Al-Kahtani, M. (2010): Renal damage mediated by oxidative stress in mice treated with aluminum chloride. J of Biological Science; 10 (7): 584-95.

- Allahverdiyev, A.; Duran, N.; Ozguven, M. and Koltas, S. (2004): Antiviral activity of the volatile oils of Melissa officinalis L. against herpes simplex virus type-2., Phytomedicine; 11: 657-661.

- Allian, C.; Poon L.; Chan, C. and Richmond, W. (1974). Enzymatic determination of total serum cholesterol. Clin. Chem.; 20: 470.

- Ballard, C.; Greig, N.; Guillozet-Bongaarts, A.; Enz, A. and Darvesh, S. (2005): Cholinesterases: roles in the brain during health and disease. Curr. Alzheimer Res.; 2:307-318.

- Bancroft, J.; Stevens, A. and Turner, D. (1996): Theory and practice of histological technique .4th Ed, New York, Churchill, Livingstone.

- Berlyne, G.; Ben-Ari, J.; Knopf, E.; Yagil, R.; Weinberger, G. and Danovitch, G. (1972): Aluminum toxicity in rats. Lancet; 299: 564-568. 
- Birdane, Y.; Buyukokuroglu, M.; Birdane, F.; Cemek, M. and Yavuz, H. (2007): Anti-inflammatory and antinociceptive effects of Melissa officinalis L. in rodents. Rev. Med. Vet., 158: 75-81.

- Bohmer, H. (1971): Micro-determination of creatinine. Clin. Chem. Acta.; 32:8185.

- Bolkent, S.; Yanardag, R.; Karabulut-Bulan, O. and Yesilyaprak, B. (2005): Protective role of Melissa officinalis L. extract on liver of hyperlipidemic rats: A morphological and biochemical study. J. Ethnopharmacol; 99: 391-398.

- Bolkent, S.; Yanardag, O.; Karabulut-Bulan and Yesilyaprak, B. (2005): Protective role of Melissa Officinalis L. extract on liver of hyperlipidemic rats.J. Ethnopharmacol.; 99: 391-398.

- Burham, P.C. (2006): Molecular basis for adaptive responses during chemically induced hepatotoxicity. Toxicol. Sci.; 89: 349-351.

- Canadanovic-Brunet, J.; Cetkovic, G.; Djilas, S.; Tumbas, V.; Bogdanovic, G.; Mandic, A.; Markov, S.; Cvetkovic, D. and Canadanovic, V. (2008): Radical scavenging, antibacterial, and antiproliferative activities of Melissa officinalis (L.) extracts. J Med Food; 11:133-143.

- Cao, G.; Alessio, H. and Cutler, R. (1993): Oxygen radical absorbance capacity assay for antioxidants. Free Radic Biol Med.; 14:303-311.

- Carnat, A.P.; Carnat, A.; Fraisse, D. and Lamaison, J.L. (1998): The aromatic and polyphenolic composition of lemon balm (Melissa officinalis L. subsp. officinalis) tea. Pharm Acta Helv.; 72:301-305.

- Carnat, A.P.; Fraisse, D. and Lamaison, J. (1998): The aromatic and polyphenolic composition of lemon balm (Melissa officinalis L. subsp. officinalis) tea. Pharm Acta Helv.; 72:301-305.

- Carvalho, L.; Cruz-Hipolito; H.; González-Torralva, F.; Christoffoleti, P. and De Prado, R. (2011): Detection of sourgrass (Digitaria insularis) biotypes resistant to glyphosate in Brazil. Weed Sci.; 59: 1711-1776.

- Chapman, D.; Castilla, R. and Campbell, J. (1959): Evaluation of protein in food. I. A. Method for the determination of protein efficiency ratio. Can. J. Biochem. Physiol.; 37: 679-686.

- Coleta, M.; Campos, M.; Cotrim, M. and Proenca Cunha, A. (2011): Comparative evaluation of Melissa officinalis L., Tilia europaea L., Passiflora edulis Sims and Hypericum perforatum L. in the elevated plus maze anxiety test. Pharmacopsychiatry; 34: 20-21. 
- Dastmalchi, K.; Dorman, H.; Oinonen, P.; Darwis, Y.; Laakso and Hiltunen, R. (2008): Chemical composition and In vitro antioxidative activity of a lemon balm (Melissa officinalis L.) extract. LWT-Food Sci. Technol., 41: 391-400.

- Domingo, J. L. (1987): Nutritional and toxicological effects of short-term ingestion of aluminum by the rat. Research communications in chemical pathology and pharmacology, 56:409- 419.

- El-Demerdash, F.M. (2004):Antioxidant effect of vitamin E and selenium on lipid peroxidation, enzyme activities and biochemical parameters in rats exposed to aluminum. $\mathrm{J}$ of Trace Elements in Medicine and Biology;18:113-21.

- Fnedewaid, W.T. (1972): Determination of HDL. Clin. Chem.; 8:499.

- Fossati, P. and Prencipe, L. (1982): Determination of triglycerides, Bicon Diagnostics, made in Germany. Clinical Chemistry; 28: 2077-2078.

- Fossati, P.; Prencipe, L. and Berti, G. (1980): Use of 3.5 dichloro-zhydroxybenzenesulfonic acid / 4 aminophenazone chromogenic systems in direct enzymic assay of uric acid in serum and urine. Clin. Chem.; 26:227- 231.

- Garcia, T.; Esparza,J.; Nogues,M.; Romeu, M.; Domingo,J. and Gomez, M. (2010): Chemical composition and in vitro antioxidative activity of a lemon balm (Melissa officinalis L.) extract. Hippocampus; 20: 218-225.

- Guginski, G.; Luiz, A.; Silva, M.; Massaro, M. and Chaves, J. (2009): Mechanisms involved in the antinociception caused by the Leaves of Melissa Officinalis (Lemon Balm) in Mice. Pharmacology, Biochemistry and Behavior; 93(1): 10-16.

- Hasani-Ranjbar, S.; Larijani, B. and Abdollahi, M. (2009): A systematic review of the potential herbal sources of future drugs effective in oxidant-related diseases. Inflamm. Allergy Drug Targets; 8: 2-10.

- Herodez, S.S.; Hadolin, M.; Skerget, M. and Zeljko, K. (2003): Solvent extraction study of antioxidants from balm (Melissa officinalis L.) leaves. Food Chem.; 80:275-282.

- Kennedy, D.; Little, W. and Schley, A. (2004): Attenuation of laboratoryinduced stress in humans after acute administration of Melissa officinalis (lemon balm). J. Pharm Pharmacol.; 56: 677-681.

- Kind, P.R. and King, E.J. (1954): Estimation of alkaline phosphatase activity by determination of hydrolyzed phenol with aminoantipyrene. J. Clin.Path.7: 322.

- Knedel, M. and Boottger, R. (1967): A kinetic method for determination of the activity of pseudo cholinesterase. Klin. Wochenschr; 45: 325-327. 
- Krewski, D.; Yokel, R.; Nieboer, E.; Borchelt, D. and Cohen, J. (2007): Human health risk assessment for aluminium, aluminium oxide and aluminium hydroxide. J. Toxicol. Environ. Health Part B: Crit. Rev.; 10:1-269.

- Kumar, V. and Gill, K. (2009): Aluminum neurotoxicity: neurobehavioural and oxidative aspects. Archives of toxicology; 83:965-78.

- Lee, R. and Nieman, D. (1996): Nutritional assessment. 2 nd Ed., Mosby, Missoun, USA.

- Mi, R. ; Beom, S.; Oh, H. and Chang, K. (2011): Comparative Study of Korean White, Red, and Black Ginseng Extract on Cholinesterase Inhibitory Activity and Cholinergic Function. J. Ginseng Res.; 35(4): 421-428.

- Mimica-Dukic, N.; Bozin, B.; Socovik, M. and Simin, N. (2004): Antimicrobial and antioxidant activities of Melissa officinalis L. (Lamiacea) essential oil. J Agric Food Chem; 52:2485-2489.

- Mohammadirad, A. and Abdollahi, M. (2011): A systematic review on oxidant/antioxidant imbalance in aluminum toxicity. Int. J. Pharmacol.; 7: 12-21.

- Nehru, B. and Bhalla, P. (2006): Reversal of an aluminum induced alteration in redox status in different regions of rat brain by administration of centrophenoxine. Molecular and Cellular Biochem.;290: 185-91.

- Newairy, A.S.; Salama, A.F.; Hussien, H.M. and Yousef, M.I. (2009): Propolis alleviates aluminium-induced lipid peroxidation and biochemical parameters in male rats. Food Chem. Toxicol.; 47: 1093-1098.

- Nishikimi, M.; Rao, N. and Yogi, K. (1972): Colorimetric determination of superoxide dismutase. Biochem. Biophys. Res. Common.; 46: 849-854.

- Ohkawa, H; Ohishi, N. and Yagi, K. (1979): Assay for lipid peroxides in animal tissues by thiobarbituric acid reaction. Anal Biochem.; 95: 351-358.

- Ohno, K.; Tsujino, A.; Brengman, J.; Harper, C.; Bajzer, Z.; Udd, B.; Robb, S.; Kirkham, F. and Engel, A. (2001): Choline acetyltransferase mutations cause myasthenic syndrome associated with episodic apnea in humans. Proc Natl Acad. Sci. U S A.; 98:2017-2022.

- Patton, C. and Crouch, S. (1977): Determination of serum urea enzymatically. J. of Ana. Chem.; $49: 464$ - 469.

- Pereira, P.; Tysca, D.; Oliveira, P.; Da Silva-Brum, L.; Picada, J. and Ardenghi, P. (2005): Neurobehavioral and genotoxic aspects of rosmarinic acid. Pharmacol Res.; 52:199-203. 
- Pereira, R.; Fachineto, R.; Prestes, A.; Puntel, R.; Boschetti, T.; Athayde, M.; Büerguer, M.; Morel, A.; Morsch, V. and Rocha, J. (2009): Antioxidant effects of different extracts from Melissa officinalis, Matricaria recutita and Cymbopogon citratus. Neurochem Res.; 34:973-983.

- Qitu, M.; Rengel, Z. and Kuo, J. (2002): Aluminum toxicity. Annals of Botany;89 (2): 241.

- Randell, E.; Mathews, M.; Zhang, H.; Seraj, J. and Sun, G. (2005): Relationship between serum butyrylcholinesterase and the metabolic syndrome. Clin Biochem.; 38: 799-805.

- Ranjbar,A.;Khani-Jazani,K.; Sedighi,A.; Jalali-Mashayekhi,F.; Ghazi-Khansari, M. and Abdollahi, M. (2008): Alteration of body total antioxidant capacity and thiol molecules in human chronic exposure to aluminum. Toxicol. Environ. Chem.; 90: 707-713.

- Reeves, P.; Nielson, F. and Fahmy, G. (1993): Reports of the American Institute of Nutrition, Adhoc Wiling Committee on reformulation of the AIN 93. Rodent Diet. J. Nutri.; 123: 1939-1951.

- Rehman, S.; Romaisa, L.; Khursheed, A.; Mohammad, A.; Khuroo, S. and Suresh, C. (2013): Comparative analysis of the aroma chemicals of Melissa officinalis using hydrodistillation and HS-SPME techniques. Arabian Journal of Chemistry. King Saud University, http://dx.doi.org/10.1016/j.arabjc.2013.09.015

- Reitman, S. and Frankel, S. (1957): Determination of serum alanine and aspartate aminotransferases (ALT \& AST). Clin .Path. Am. J.; 28: 57-63.

- Sadraei, H.; Ghannadi, A. and Malekshahi, K. (2003): Relaxant effect of essential oil of Melissa officinal is and citral on rat ileum contractions. Phytother. Res.;17: 599-604.

- Salah, S.M. and Jäger, A.K. (2005): Screening of traditionally used Lebanese herbs for neurological activities. J Ethnopharmacol ; 97:145-149.

- Sanchez-Iglesias, S.; Mendez-Alvarez, E.; Iglesias-Gonzalez, J.; Munoz-Patino, A.; Sanchez-Sellero, I.; Labandeira-Garcia, J.L. and Soto-Otero, R. (2009): Brain oxidative stress and selective behaviour of aluminium in specific areas of rat brain: potential effects in a 6-OHDA-induced model of Parkinson`s disease. J. Neurochem.; 109: 879-888.

- Sarı, A. and Ceylan, A. (2002): Yield characteristics and Essential oil composition of lemon balm (Melissa officinalis L.) grown in the Aegean Region of Turkey. Turk. J. Agric. For.; 22: 217-224. 
- Sharafzadeh, S.; Khosh-Khui, M. and Javidnia, K. (2011): Effect of nutrients on essential oil components, pigments and total phenolic content of lemon balm (Melissa officinalis L.). Advances in Environmental Biology; 5(4):639-646.

- Sharma, D.; Sethi, P.; Hussain, E. and Singh, R. (2009): Curcumin counteracts the aluminum induced ageing related alteration in oxidative stress. Biogerontol;10: 489-502.

- Shati, A. and Alamri, S. (2010): Role of saffron and honey on aluminum induced hepatotoxicity. Saudi Medical J.;31 (10): 1106-13.

- Snedecor, G.W. and Cochran, W.G. (1967): Statistical Methods; 7th Ed., The Lowa State University Press., Ames, Lowa, U.S.A.

- Souza, A.C.; Alviano, D.S.; Alves, P.B.; Alviano, C.S. and Gattass, C.R. (2004): Melissa officinalis L. essential oil: Antitumoral and antioxidant activities. J Pharm Pharmacol; 56:677-681.

- Stoehr, G.; Leubbers, K.; Wilhelm, M.; Hoelzer, J. and Ohmann, C. (2006): Aluminum load in ICU patients during stress ulcer prophylaxis. European $\mathbf{J}$ of Internal Medicine; 17:561-6.

- Turkez, H.; Yousef, M. and Geyikoglu, F. (2010): Propolis prevents aluminuminduced genetic and hepatic damages in rat liver. Food and Chemical Toxicology;48: 2741-6.

- Vieželienè, D.; Rodoviius, H. and Ivanov, L. (2006): Effect of aluminum ions on the activities of tRNALeu and leucyl-tRNA synthetase in mouse liver in vivo and in vitro. Biologija; 4: 28-30.

- Ward, R.; Zhang, Y. and Crichton, R. (2001): Aluminum toxicity and iron homeostasis. J of Inorganic Biochem.;87(1-2):9-14.

- Yamasaki, K.; Nakano, M.; Kawahata, T.; Mori, H.; Otake, T.; Ueba, N.; Oishi, I.; Yamane, M.; Nakamura,M.; Murata, H. and Nakanishi, T.(1998): Anti- HIV-1 activity of herbs in Labiatae. Biol. Pharm. Bull.; 21: 829-833.

- Zeraatpishe, A.; Oryan, S.; Bagheri, M.; Pilevarian, A.; Malekirad, A.; Baeeri, M. and Abdollahi, M. (2011): Effects of Melissa officinalis L. on oxidative status and DNA damage in subjects exposed to long-term low-dose ionizing radiation. Toxicol. Ind. Health; 7: 205-212. 


\section{تأثير الميليسا علي الإجهاد التسأكسدي والمؤشرات الميهوية للفئران \\ المسمهمة بالألموهونيوم}

"نهال محمد بلال"

الملخص العربي

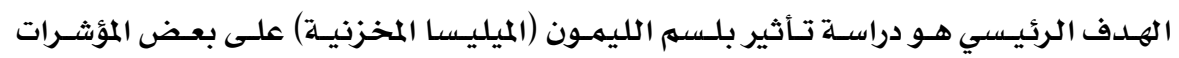

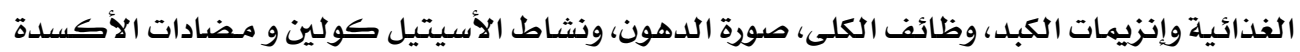

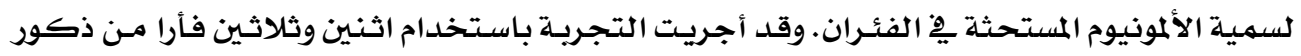

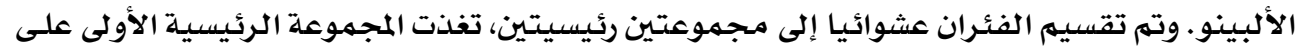

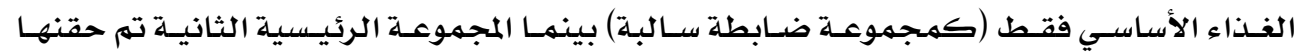

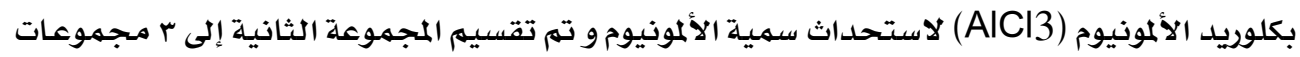

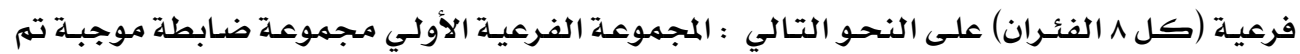

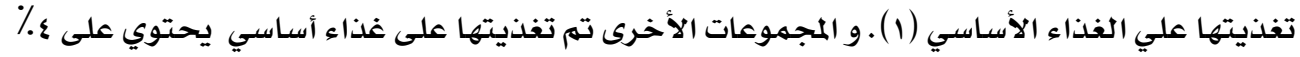

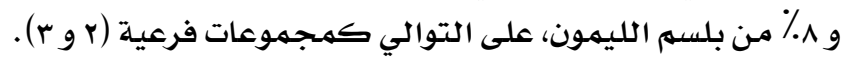

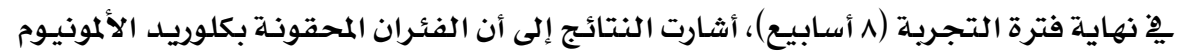

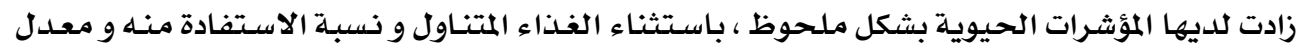

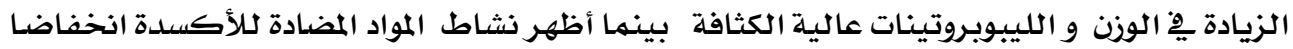

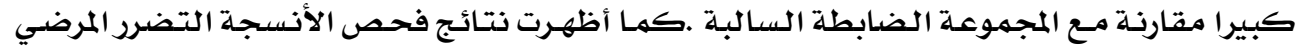

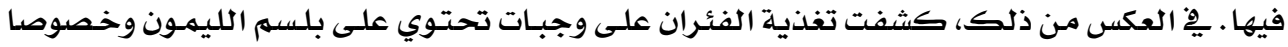

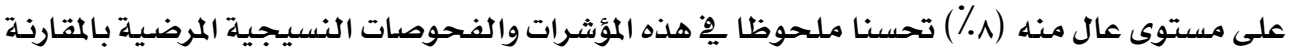

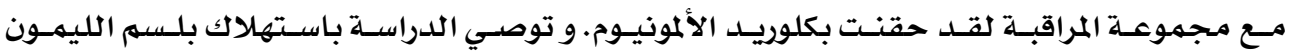

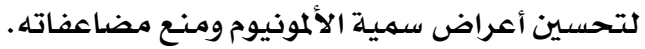

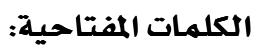
الميليسا - كلوريد الألومونيوم - الأسيتيل كولين - مضادات الأكسدة.

قسم التغذية و علوم الأطعمة - كلية الاقتصاد المنزلي - جامعة حلوان 